\title{
Breed Code
}

National Cancer Institute

\section{Source}

National Cancer Institute. Breed Code. NCI Thesaurus. Code C93523.

A coded value specifying a group of animals presumably related by descent from common ancestors and visibly similar in most characteristics. 